Article

\title{
Souls in the Dark: \\ Theodicy and Domesticity in Home
}

\author{
Mark S. M. Scott \\ Department of Religious Studies, Thorneloe University at Laurentian, 935 Ramsey Lake Road, Sudbury, \\ ON P3E 2C6, Canada; mscott4@laurentian.ca; Tel.: +1-705-673-1730 (ext. 403)
}

Received: 17 October 2017; Accepted: 15 December 2017; Published: 19 December 2017

\begin{abstract}
Theodicy typically addresses the problem of evil in the public square, focusing on instances of paradigmatic evil that raise the issue broadly. Theodicy, however, also operates in the private sphere, where the conflict and chaos of family life raise doubts about God's goodness and power. Domestic suffering - here defined as the hurt, sorrows, and heartbreaks of family life, apart from domestic abuse, which belongs to a separate category - has often been neglected by theodicists. In this article, I will analyze Marilynne Robinson's fictional novel Home for insights into the problem of evil in the domestic realm. While it does not offer a domestic theodicy per se, Robinson's Home sheds light on the reality of suffering love and its bias toward hope, which charts new theological pathways in theodicy that have hitherto been underexplored.
\end{abstract}

Keywords: Marilynne Robinson; Home; Gilead trilogy; problem of evil; theodicy; suffering love; hope

"But the soul finds its own home if it ever has a home at all" (Home, 282)

Classic theological and philosophical treatments of the problem of evil cast the question onto a vast canvass, enumerating the most egregious examples of suffering around the globe, both historically and currently. Most often, these are infamous spectacles whose shockwaves were felt far and wide: the Plague, the Inquisition, the Lisbon Earthquake, the World Wars, the Holocaust, 9/11, and so on. These and other instances of public, superlative evils are nodal points for the problem of evil, and rightly so. But what about the problem of evil as it arises in private life, within the walls of our homes, in the complex, sometimes strained, sometimes severed relationships between immediate family members? More subtle than traditional instantiations, they nonetheless raise the problem in an important—often neglected—register. Hemingway notes the "intimate harm" that family sometimes inflict (Hemingway 1964, p. 88). Where would we begin an analysis of theodicy in the domestic realm, especially given its frequent invisibility?

Marilynne Robinson provides a portal through which to undertake an oblique analysis of theodicy in her novel Home (Robinson 2008), the second of her Gilead trilogy, interposed between Gilead (Robinson 2004) and Lila (Robinson 2014). All three novels shed light on the problem of evil, but from different vantage points. Gilead explores the interplay between beauty and suffering (Scott 2016). Lila ponders the mystery of suffering and grace (Scott 2017). Home, while absorbing these themes, hones in on suffering love and hope. My essay will analyze Home in three stages. First, I will select five portraits of pain from the novel that illustrate the problem of evil as the problem of suffering love. Second, I will briefly draw from theologians and philosophers to expound on the relationship between love and suffering in a world of woe. Finally, I will sound the notes of hope that temper the tragedy of Home without bypassing it. 


\section{Portraits of Pain: Five Vignettes}

\subsection{Jack Boughton: Troubled Soul}

The problem of evil in Home, as in the entire Gilead trilogy, centers on Jack Boughton, the prodigal son of local Presbyterian minister Robert Boughton. All the other characters buffet and break against the rock of Jack's reprobation. He represents the problem of evil generally and specifically. Firstly, at a general level, it seems unjust that an all-loving, all-powerful God would inflict his family with the pain of his inexcusable misdeeds, which escalate in severity and significance as he gets older. As paragons of virtue, the Boughtons enjoyed the esteem of nearly all, but Jack's antics as "the black sheep, the ne'er-do-well" cast a shadow over their reputation (69). Why would God allow these good parents and siblings to be tormented by their often selfish and destructive prodigal son and sibling? Why would God not intervene to convert him or to change his character? Why would God allow them to suffer their whole life on his account?

But Jack also illustrates the problem specifically in his enduring experience of estrangement (85). From the moment he stands tentatively on the back porch, unsure of his welcome, until the time he leaves, he never feels at home $(30,318)$. He shies away from physical contact, avoids intimate conversation, and never enjoys the sense of full inclusion, always living on the outskirts of the family, asking permission for things that his father and sister insisted were his to enjoy as much as theirs. In one memorable moment, Glory gives Jack a haircut, at his request. Though unremarkable on the face of it, given Jack's aversion to physical contact, his request comes as a surprise. He fidgets uneasily at her touch, unused to it (171) and tears up in "exasperation": "I'm so tired of myself" (172). Unable to feel home with himself, he cannot feel at home with others, even in his family home, and so he remains inexplicably estranged (267).

Jack's self-estrangement and self-loathing eventuates in a botched suicide attempt in the barn, his hidden oasis from the joyful commotion of the Boughton family life since he was a boy. In a state of drunken despair, he stuffed his shirt and socks into the tailpipe of the DeSoto and courted oblivion, only forestalled by his inability to start the car without the keys, which he gave to Glory (243-44). It was the family's greatest fear: "Was this what they had always been afraid of, that he would really leave, that he would truly and finally put himself beyond the reach of help and harm, beyond self-consciousness and all its humiliations, beyond all that loneliness and unspent anger and all that unsalved shame, and their endless, relentless loyalty to him?" (247-48). After the initial shock of finding him, Glory discreetly washes him and helps him into bed, but the episode signals the end of Jack's hopes for happiness. He has given up on himself (208).

\subsection{Robert Boughton: Tortured Soul}

Jack's elusiveness and estrangement weighed heavily on his parents, who could never make him feel at home in the world $(170,230,267)$. At every age, they tried to alleviate his alienation and loneliness. His father Robert Boughton constantly affirmed his love for Jack. When, as a child, a malicious neighbor sarcastically told Jack that his parents deserved him, his father responded graciously: "Well now, that was kind of her. I will be sure to thank her. I hope I do deserve you, Jack" (13). All they ever hoped for him was happiness, but Jack could never shake his "sadness" and "heavyheartedness" (115). If, as they say, you are only as happy as your saddest child, then their hopes were unrealized, so Robert "tried not to hope for anything at all, except that we wouldn't lose you. So of course we did" (116). For his whole life, Jack was an open wound for Robert Boughton and his wife: an unanswered prayer that darkened their otherwise sunny skies.

Despite his lifelong "posture of heroic and fatherly grace" (24), Robert finds himself unable to maintain his practiced magnanimity upon Jack's return, even though it was the answer to decades of fervent prayer. The years have taken a toll on him: "Kindness takes more strength than I have now .. Maybe I'm finding out I'm not such a good man as I thought I was. Now that I don't have the strength-patience takes a lot out of you. Hope, too" (274). Age and weariness interrupt the flow of his unlimited supply of grace to Jack. Near the end of his life, he reflects on his failure to protect Jack 
from himself: "You see something beautiful in a child, and you almost live for it, you feel as though you would die for it, but it isn't yours to keep or to protect" (294-95). In the end, as Jack extends his hand to bid his father farewell, Robert withdraws his hand and turns away from him in exhaustion, confusion, and despair: "Tired of it!" (317).

Crippled by age and diminished by disappointment, Robert's "posture of grace" finally wears out (45). Jack does not blame him, nor does he walk away in anger. He kisses his father on the brow, a hint of hope in an otherwise hopeless situation. Robert's inability to assume the role of the prodigal's father, ready to forgive and to celebrate the return of the prodigal son, was a failure of frailty, not of faith. But, unlike the parable (Luke 15: 11-32), where the older brother resents the father's welcoming reception of the son, Jack's older brother Teddy picks up the mantle dropped by their father, and gives him the parting embrace that his father denies him: "II suspect I'll never see you again. In this life. I'd say take care of yourself, but I'm afraid you won't do that either. Well, never hesitate-' He held out his hand. When Jack took it, he touched his shoulder, then embraced him" (268). Teddy completes his father's legacy of grace to Jack.

\subsection{Glory Boughton: Good Soul}

Though heroic in his unflagging love for Jack, Glory emerges in Home as the true heroine of the story, and as the custodian of grace and hope for Jack. 38-year-old Glory returns to the family home in Gilead after a long and humiliating engagement to a married man $(7,22,118,149)$. Duped by him for years, she finally sees through the charade, left only with the memory of the love she imagined they shared. One night, she dumped her "fiancé's" 452 love letters and her "cheap ring" down a storm drain, a symbolic gesture of the end of their relationship and her illusions about him (119). As false tokens of feigned love, they were deposited where they belonged: down the drain: "It was all horrible enough to be funny, I suppose, Now that it's over" (119). Glory's innate honesty and soft-spot for hard-luck cases made her the perfect mark for her "ex-fiancé's" avarice or affection (or both), and now she finds herself unhappy at home (131).

When Jack returns to Gilead, it gives her a renewed purpose, but also new worries and problems. In their younger years, Glory felt a special bond with Jack, the most enigmatic of her seven siblings, and five years her senior. When he impregnated a local teenager, who gave birth to a daughter, Glory took great pains to help the mother and child. She wrote letters imploring Jack to come home and take responsibility for his daughter, but he never did (150). Nevertheless, her love for him was undiminished, and she expressed it in her attentiveness to his daughter. More than once, Jack affectionately calls Glory "a good soul” $(118,149)$. Although he would never know the kindnesses she did for him in those years (70), he appreciated her tender care for him now: "Everything would be so much harder if you weren't here. Impossible, in fact" (131; cf. 316). Despite all the sorrow Jack caused in the past and present, she loves him selflessly.

Glory's inexhaustible, altruistic love for Jack takes on epic proportions, however, in her decision to stay in Gilead-in a town she hates, in a house she does not want-because Jack loved it in his own way $(299-300,323)$. The memory of his presence in it, both when they were younger and now, endows it with a sacredness she chooses to cherish. His wistfulness for it and the stories he told his wife Della about it augment its value to her $(104,320)$. She also keeps it as a haven of hope for Jack: "Now you know where to come when you need help ... If you ever need to come home, I'll be here" (316-317). In an act of breath-taking sacrificial love, she commits to forgo her own hopes and dreams to keep the home fires burning for him, as a grand gesture of love and hope. "Good" falls far short of capturing the calibre of Glory's soul, but it is a soul forged in the fires of Jack's past and present abandonment of her and his responsibilities.

\subsection{Baby Boughton: Lost Soul}

The dark secret that haunted Jack was his abandonment of the child of his youth and her mother, Annie Wheeler, a poor teenager $(233,276)$. Jack confides his struggle with guilt to Glory: "Say you do 
something terrible. And it's done. And you can't change it. Then how do you live the rest of your life?" (99). His father Robert was "stunned" and "winded" by it, but he never failed to extend grace (7). Jack believed that his father found it unforgiveable, which deepened his sense of estrangement: "I knew I had done something he couldn't forgive. He thought he could. He said he had, but he's a terrible liar. It shocked me that I could hurt him so badly. It scared me" (277). Thus began Jack's 20-year self-exile from Gilead. Glory filled in for Jack as best as she could, herself only a teenager, but in the end the baby died of an infection, perhaps the fault of negligence-poor living conditions-or perhaps simply the nature of human frailty (234).

The unnamed child was the collateral damage of Jack's selfishness and irresponsibility. Though lost to the world before her time, she brought joy to her mother, Glory, and presumably both sets of parents, despite the scandal that caused her existence in the first place. Loved in life and in death, she remained for Glory and Robert part of the family. For Jack, however, she only reminded him of his misspent youth and his moral failings. For Glory, the mere mention of Annie Wheeler or her child brings tears to her eyes, but she does not regret their existence (150). They brought joy to their life, and she wants Jack to know that, to ease his conscience. The affair demonstrates the interconnectedness of suffering: Jack's actions ripple through two families. But at the center of the devastation was an innocent little girl who never knew her father, never knew family stability, and ultimately fell victim to conditions she did not create and could not prevent.

\subsection{Robert Boughton, Jr.: Restless Soul}

We do not learn of the secret treasure of Jack's heart until the final pages of Home, although readers of Gilead will remember: "Jack Boughton has a wife and a child" (Robinson 2004, p. 217). Guarded and distrustful, as well as protective of their feelings, Jack never told them about his son, but when Della visited their home with her boy, Glory suddenly realized: "Jack had a beautiful child, a beautiful son" (322). He plays baseball and wants to be a preacher, and he loves his father, who has disappointed him again by his absence. We do not know much else about him (Gilead fills out the picture), but we can reasonably infer that he will always wonder about his father, even if he has a fine step-father one day. He will ask himself why his father left them, why he could not hold a job, and why his life was so hard. Jack's absence plants a seed of restlessness that might one day set him on a journey to discover the answers, such as they are.

\section{Theodicy and Domesticity: A Theological Analysis}

\subsection{Suffering Love: "Love is Tears"}

These five vignettes illustrate the reality of suffering love, especially in family life, often the site of our most intimate and immediate encounters with sorrow. All the characters suffer because of their love for Jack, whose estrangement taints their happiness and whose despair imperils their joy. Does Robinson's attention to the inexorable connection between love and suffering in the novel constitute a nascent domestic theodicy? No, but it does draw our attention to an important facet of theodicy, found especially in cruciform theodicies, that love suffers (Scott 2015, pp. 145-72). Poets and playwrights have understood this inescapable principle of life, and it opens theological vistas into the mystery of suffering, even if it does not solve the problem of evil. If her foray into domestic suffering might leave the analytic philosopher unsatisfied, it might at least stimulate an analysis of the theological implications of suffering love for theodicy.

First, to love is to suffer: live long enough, love deeply enough, and life will break your heart into a thousand pieces. Jürgen Moltmann argues that divine love entails divine suffering: "The God who is love, and who loves every one of his creatures with a love that is infinite, is bound to experience sorrow ..." (Moltmann 1993a, p. 39). God cannot be impassible because that would undercut love: "For a God who is incapable of suffering is a being who cannot be involved ... He cannot weep, for he has no tears. But the one who cannot suffer cannot love either" (Moltmann 1993b, p. 222). Nicholas Wolterstorff, reflecting on the death of his son, concurs: "Love in our world is suffering love ... God 
is love. That is why he suffers ... Suffering is the meaning of our world. For Love is the meaning. And Love suffers" (Wolterstorff 1987, pp. 89-90). In a poem, C. S. Lewis succinctly summarizes the correlation: "Love is tears" (Lewis 1964, p. 123).

The concept of perichoresis or circumincessio illuminates the theological grounding of suffering love (McGrath 2016, p. 453). Theological anthropology posits as its first principle that humans are created in the image of God (Genesis 1: 26). In finite, flawed ways, humans mirror the divine life. God, conceived as Trinity, exists in an eternal interplay of Father, Son, and Spirit where the three Persons are internal to one another. Perichoresis signifies the mutual indwelling or co-interpenetration of the Persons: in any one Person, the other two are eternally present. Thus, they exist in an indissoluble, ineffable unity. Humans mutually indwell each other too, not ontologically (as with God), but emotionally. Love creates room for another inside the self, which makes it vulnerable to the pain of loss, rejection, and disappointment. The other's pain, then, becomes internal to the self, since their well-being has merged with it, as we see in Home.

So suffering love signifies the human capacity to internalize the suffering of another. Insofar as it co-suffers compassionately and empathetically, it reflects the love of God, which suffers in solidarity with human suffering, for human sinfulness, and by human hands, as Moltmann explains: "The suffering of God with the world, the suffering of God from the world, and the suffering of God for the world are the highest forms of creative love, which desires free fellowship with the world and free response in the world" (Moltmann 1993a, p. 60). Suffering love, therefore, represents the highest manifestation of human love, often displayed in families. While the concept of suffering love in God and in human relationships does not formally solve the problem of evil, it charts a theological trajectory that takes theodicy in new directions (such the domestic realm) and contains new resources for reflection (i.e., redemptive suffering).

\subsection{Hope: Souls in Waiting}

After 20 years of worrying, Jack's father knew the intimate connection between love and suffering. The only possible way to alleviate his suffering was to sever his love, which he tried, unsuccessfully: "So many times, over the years, I've tried not to love you so much. I never got anywhere with it, but I tried. I'd say, He doesn't care a thing about us ... . Your mother always said, You imagine some happiness is going to come out of all this, all this waiting and hoping, but it never will. So I tried to put an end to it. But I couldn't" (272-73). Robert could no more stop loving Jack than he could stop believing in the happy ending his wife warned him against. She died without knowing Jack's whereabouts or seeing him again (58), but Robert hung on to life long enough to see him again and, in his mind, that was vindication for hope, and of the "goodness of the Lord" (274), the verification of which awaited Jack's arrival, in his mind.

But hope seems in woefully short supply in Home. Old age and ill health prevent Robert from sustaining the grace he cultivated a lifetime to give to Jack. Jack attempts suicide, gives up on his dream of making a life together with his wife and son, and leaves town just before his brothers and sisters converge on Gilead to pay their final respects to their dying father. So there is no Boughton family reunion, no restoration of Jack to his wife and son, and the baby girl of his youth remains buried beneath the earth. His long-anticipated and celebrated return to Gilead after 20 years of unexplained absence yields no results-nothing has changed: Jack remains alienated from his family and himself, his misdeeds remain unredeemed, and his dreams are shattered. Domestic suffering does not always have happy endings, so it should come as no surprise that Robinson denies readers forced or facile resolutions in Home. Though grim, it is not hopeless.

Glory envisions a future where she stays at the family home as a gesture of hope and as a tribute to their love for Jack. She imagines Jack's boy, her nephew, returning as a young man, in search of his roots. "He will talk to me a little while, too shy to tell me why he has come, and then he will thank me and leave, walking backward a few steps, thinking, Yes, the barn is still there, yes, the lilacs, even the pot of petunias. This was my father's house. And I will think, He is young. He cannot know that 
my whole life has come down to this moment" (324-325). Glory embodies the hope that Jack's wife and son will find peace, which might bring him peace. And if Jack never finds peace with himself and others on the open road, if it eludes him until the end of his weary days, perhaps he will find peace on the other side of eternity, answering the unceasing prayers of his family, and completing their unrealized felicity (316). What else is heaven for?

\section{Conclusions}

It does not take a family reunion to realize the messiness of family life, although they inevitably underscore it. Most of us live it every day, in one way or another, to varying degrees of severity. Sometimes suffering love for family cuts to the bone. Relationships fail. Hearts break. Hope fades. Suffering love, however, refuses to give up, even when "there never was much hope ... just a fool's hope" (Tolkien 1955, p. 83). But love always hopes, Paul tells us (1 Corinthians 13: 7), so hope refuses to let brokenness have the last word. When and how restoration finally comes remains a mystery, as Robinson's novel intimates with Glory's expectant waiting at the family home for Jack, for his son, and for peace, but it never gives up. In a world of relentless sorrow, we strive to make home a shelter from the storm, a refuge from the slings and arrows of life. Sometimes it is a haven, sometimes it is a hell, and sometimes it vacillates between the two.

Home illustrates a forgotten facet of theodicy: domestic suffering. For our purposes, domestic suffering refers not to the painful experiences of abuse that fit under the category of horrendous evils (Adams 1999), but to the ways families fail to save each other from their worst impulses, and how they light a candle of hope even after the failure. Domestic suffering denotes the suffering love of family life, and its bias toward hope. Theodicy often operates in the visible space of "paradigmatic evil": instances of horror that raise the problem of evil publicly (Scott 2015, pp. 49-51). But for many, the problem of evil surfaces invisibly in their private lives, in the hurt and heartache of broken relationships, in the unreachable pain of others that we internalize. Where is God then? Robinson's novel narrows the focus to the intimate experiences of suffering in family life, and to the inextinguishable love that guides souls in the dark to the light of hope.

Conflicts of Interest: The author declares no conflict of interest.

\section{References}

Adams, Marilyn McCord Adams. 1999. Horrendous Evils and the Goodness of God. Ithaca: Cornell University Press. Hemingway, Ernest. 1964. A Moveable Feast. New York: Scribner.

Lewis, C. S. 1964. Poems. Edited by Walter Hooper. New York: Harcourt Brace \& Company.

McGrath, Alister E. 2016. Christian Theology: An Introduction, 6th ed. Malden: Wiley-Blackwell.

Moltmann, Jürgen. 1993a. The Trinity and the Kingdom: The Doctrine of God. Translated by Margaret Kohl. Minneapolis: Fortress Press.

Moltmann, Jürgen. 1993b. The Crucified God: The Cross of Christ as the Foundation and Criticism of Christian Theology. Translated by R. A. Wilson, and John Bowden. Minneapolis: Fortress Press.

Robinson, Marilynne. 2004. Gilead. New York: Picador.

Robinson, Marilynne. 2008. Home. New York: Picador.

Robinson, Marilynne. 2014. Lila. New York: Farrar, Straus and Giroux.

Scott, Mark. S. M. 2015. Pathways in Theodicy: An Introduction to the Problem of Evil. Minneapolis: Fortress.

Scott, Mark S. M. 2016. Beauty from Ashes: Aesthetic Transformations of Suffering in Gilead. CRUX 52: 11-18.

Scott, Mark S. M. 2017. Wrestling with Existence: Pondering Suffering and Grace in Lila. Toronto Journal of Theology, 33, forthcoming. [CrossRef]

Tolkien, J. R. R. 1955. The Lord of the Rings: The Return of the King. New York: Ballantine Books. Wolterstorff, Nicholas. 1987. Lament for a Son. Grand Rapids: Wm. B. Eerdmans Publishing Co. 